\title{
INVESTIGATION INTO RESPONSIBLE TOURISM TOURS IN BUDAPEST, HUNGARY
}

\author{
NGUYEN THI THANH NGA, ÉVA ERDÉLYI \& KATALIN FORMÁDI \\ Faculty of Commerce, Catering and Tourism, Budapest Business School, Hungary
}

\begin{abstract}
The travel and tourism industry is highly competitive and tour operators are under increasing pressure to differentiate their products. One such product, responsible tourism, is considered as a niche market opportunity for competitive advantage. It became obvious that responsible tourism helps tour operators to reduce the negative impact of mass tourism and increases the positive impacts on economic, social and environment. This research aims to understand the theory of sustainable and responsible tourism. We based our work on qualitative and quantitative methodologies. These include the analysis of primary documents and in-depth interviews with the visitors towards the tourists' perceptions of responsible tourism packages and their demand. The survey was designed and developed according to the aims of the research. Responsible tourism should be promoted whether more tourists than ever before are interested in the responsible tourism package or not. It is important to investigate sustainable tourism practices by the travel industry in Budapest, Hungary. In fact, the key problem identified by the research was that there was a lack of responsible tourism tours in Budapest. This finding leads us to give the advice to tour operators to improve the quality of responsible tourism. Therefore, tour operators and travel agencies should create different responsible tourism tours for different tourist segments. Tourism programmes should help visitors take action and get a meaningful experience.

Keywords: sustainable tourism, responsible tourism, responsible tourism tours, corporate social responsibility, Budapest, Hungary.
\end{abstract}

\section{INTRODUCTION}

The international community has become aware of the negative effects produced by mass tourism since the 1980s. These impacts fall mainly under three headings (economic, sociocultural and environmental). Therefore, the concept of sustainable development in tourism has started to introduce and have been considered alternative to mass tourism. Sustainable tourism development emphasizes the need to preserve the traditions and the socio-cultural identity of the local community [1], to protect the environment, to generate revenue and labour for host destinations [2], [3], and finally to involve the local community in decisionmaking process of the tourism industry [2].

Moreover, the concept of responsible tourism started to emerge at the same time of the promotion of sustainable tourism. "Responsible tourism has to do with an everyday lifestyle that promotes cultural and biological diversity, and promotes environmental and natural resources conservation, at home and while traveling" [4]. According to Harold Goodwin, director of the International Centre for Responsible Tourism at the Leeds Metropolitan University, "Responsible tourism is about making better places for people to live and better place for people to visit" [5].

Hungary tourism, lacks responsible tourism practices. Therefore, we did this research to investigate "Responsible tourism tour" in Budapest. This research implemented a survey to assess the tourist's awareness of responsible tourism and their demand. As a result, we suggested solutions for tour operators and travel agency to improve the quality of tour packages. The case study itself not only is interesting for the practice of responsible tourism but also presents an opportunity to critically evaluate the conceptual and practical contribution that the concept of 'responsible tourism' might make in tourism studies. 


\section{LITERATURE REVIEW}

\subsection{Sustainable tourism}

According to the UNWTO (United Nation's World Tourism Organisation) [6], sustainable tourism development can be defined as the tourism that "meets the needs of the present tourists and host regions while protecting and enhancing the opportunity for the future. Besides that, it was the report of the World Commission on Environment and Development which defining sustainable development as "Development that meets the need of present without compromising the ability of future generations to meet their own needs" [5]. Sustainable tourism may be regarded most basically as the application of the sustainable development idea to the tourism sector. Sustainable tourism involves the minimization of negative impacts and the maximization of positive impacts. In order to promote sustainable tourism, there were lots of organizations have been established since 1992. The United Nations was the primary example of the formal recognition of sustainable tourism within global multilateral organizations. The seventh session of the UN Commission on Sustainable Development in 1999 was largely focused on the issue of sustainable tourism. The Organization for Economic Cooperation and Development (OECD) is a major international organization focused on fostering free markets and democratic governance. Through its Tourism Committee, The OECD aims to adjust their policies and actions to support sustainable growth in tourism. At a regional level, European multilateral institutions have been especially proactive informally promoting sustainable tourism since the Rio Earth Summit. The European Commission has identified sustainable tourism as one of five priority areas in the Fifth Community Programme for Environment and Sustainable Development [7].

\subsection{Responsible tourism}

The concept of responsible tourism started to emerge at the same time of the promotion of sustainable tourism development. It is not an easy task to understanding the meaning of responsible tourism. According to the Responsible Travel Handbook [4], "responsible tourism goes beyond fancy packaging and eco-certification. It also goes far beyond simplistic internal hotel policies of washing sheets and towels, or accommodations simply being located in a natural jungle or forest areas. Responsible tourism has to do with an everyday lifestyle that promotes cultural and biological diversity and promotes environmental and natural conservation, at home and while traveling" [4]. It means that tourist should take a responsible behaviour not only during the trip but also when they buy and consume everyday products or services.

According to Clifton and Benson [8], responsible tourism concept has changed from being defined as a form of tourism characterising developing countries or destinations at the early stage of the life cycle. It has a new way to conceive holidays, a sort of new lifestyle [9] pushing a growing number of people [10] to make their travel choices according to values like consciousness, sobriety [11], responsible consumption and respect for the cultural, social, environmental and economic context of the local community.

European Charter for Sustainable and Responsible Tourism [12] had a new contribution to responsible tourism definition which was a document developed by the European Union. The document aimed at presenting a common reference point for all stakeholders in tourism and defining nine supplements (basic) principles that encourage the development and implementation of responsible policies and behaviour. It is not only responsible for decisions, actions and policies but also involved in the planning, management, delivery and 
consumption of tourism. The charter specifies that responsible tourism makes possible a sustainable development of tourism.

\subsection{Forms of tourism related to responsible tourism}

The proliferation of many correlated concepts in the public domain-sustainable tourism, ecotourism, fair-trade tourism, rural tourism, community-based tourism, pro-poor tourism, etc. - which are often defined as similar to responsible tourism [4].

According to the International Ecotourism Society (TIES) [13], ecotourism identifies "responsible travels to natural areas that conserve the environment and improve the wellbeing of local people". TIES' definition seems to consider ecotourism as a form of responsible tourism.

The definition of ecotourism which argues that it should meet three criteria:

- it provides for environmental conservation;

- it includes meaningful community participation;

- it is profitable and can sustain itself.

The three contributions represent the best-known definitions of ecotourism. It shares the same principles which are focused on the environment; cultural preservation and on the profitability of the local community.

Fair-trade is another form of tourism that is related to responsible tourism. It aimed at helping producers to make better trading conditions and promote sustainability. Fair-trade tourism brings fair trade values into travel. "This means working with the travel industry to make things fairer for people living in what are traditionally known as "destinations". Fairtrade tourism is guiding the way toward sharing benefits more equitably between travelers, the tourism industry, governments of the countries visited, and most importantly, the hostcountry nationals" [4].

Education tourism overlaps with urban alternative tourism to the extent that most of the post-secondary institutions that host international and domestic student tourists are located in urban centers. However, it is distinct from another form of alternative tourism in that few students who meet the WTO [14] definition of an "educational tourist" identify themselves as tourists. Similarly, the business and organizations that have been spawned by international education are only tangentially associated with the larger tourism industry. Patterns of motivation (education, learning), travel arrangements (FIT), interactions with local residents, spatial distribution and consumption of locally produced goods and services, nevertheless, all serve to suitable education tourism within alternative tourism.

Wearing [15] reports "Volunteer tourism encompasses a diverse array of experience and settings that involve tourists who receive no financial compensation while undertaking various forms of, usually, organized social and/or environmental work in the destination". It is explicitly associated with enhancement sustainability, notable not just from the destination perspective, but also in terms of the personal development of the participating tourist. Another distinctive characteristic is the extent to which volunteer tourism is associated with environmental, religious and social non-profit NGOs (non-governmental organizations) based in major origin regions.

2.4 Comparing definitions (sustainable tourism vs. responsible tourism)

Differentiating the concept of sustainable tourism from responsible tourism is not an easy task. There were a high number of definitions were given with similar and ambiguous 
meanings. Sustainable has a broader meaning because it refers to the planning of development policy and management strategy for destination respecting and interests of all stakeholders.

Responsible tourism would mean the adoption by tourists of a travel behaviour that push them to respect the places they visit and the people they meet during the holiday and to promote the well-being of the host community. In other words, responsible tourism is a broad concept that includes different conscious and respectful ways of traveling, which bring people to take responsibility for their actions. Sustainable tourism represents the natural reply that tourist operators give in order to fulfill the needs and wishes of responsible tourists.

\section{METHOD}

According to the literature on mixed methods research, for the purpose of our study, a doublestage methodology in which qualitative research acts as preparation for a quantitative study was adopted. The qualitative and quantitative research was carried out. Based on the findings from the qualitative phase and an extensive literature review a questionnaire was designed to be used in the quantitative phase of the study [10], [16], [17]. This study is based on a survey of individuals who visited Budapest (Hungary). Especially, the qualitative study, the message explained the purpose of the research and asked individuals to provide a detailed description of their best experiences as responsible tourists. After this introductory grand tour question, we asked them to write about their motivations and how are they satisfied with the package tour in Budapest. In total, 200 descriptions were collected in three weeks. We choose random sampling method to collect our questionnaire because they are convenient.

\section{RESULTS}

The survey on assessment of responsible tourism tour in Budapest involves a necessity of defining particular actions within the responsible behaviour of tourist and the travel company. In this survey, we have focused on the awareness of visitors of responsible tourism, their behaviour and their demand. Moreover, we can assess the quality of the tour package from the visitor's point of view.

The simple random selection method was used in the survey. There was exactly the same probability of selecting each visitor participated in the Responsible Tourism Tour. The sample has been divided according to the following criteria: nationality, age, gender, career, and education. 200 correctly completed questionnaires were received. There were 200 questionnaires collected in 2017.

Most of the visitors come from European countries. Characteristics of respondents by gender indicates the dominant participation of women in the survey $(53 \%)$. In contrast, men constituted a slightly smaller group (47\%). People aged 31-50 years old were the largest group among the surveyed sample (38\%), followed by $18-30$ years old $(26 \%), 51-65$ years $(19 \%)$, under 18 years $(9 \%)$ and more than 65 years $(8 \%) .58 \%$ of the visitors have a bachelor's degree, $19 \%$ of tourists have graduated from high school, $12 \%$ respondents have higher education.

The fact that $35 \%$ of visitors haven't heard about responsible tourism while there was $45 \%$ of them met up with this concept but do not know what exactly it is. It was only $20 \%$ of visitors understood the concept of responsible tourism. These results indicate a low awareness of visitors about the concept of responsible tourism.

Table 1 shows that percentages of visitor participate in responsible activities. It is clear that the largest proportion of visitor agrees to take part in responsible tourism activities. When they choose the responsible tourism tour, they will visit the Hungarian Market and explore the local culture from their gastronomy. Moreover, tourists visited some famous place to 
Table 1: Activities related to responsible tourism undertaken by tourists (\%). (Source: Calculations on the basis of the survey, 2017.)

\begin{tabular}{|l|c|c|c|c|c|}
\hline \multirow{2}{*}{ Criteria } & \multicolumn{5}{|c|}{ Scale } \\
\cline { 2 - 6 } & $\begin{array}{c}\text { Strongly } \\
\text { disagree }\end{array}$ & Disagree & Neutral & Agree & $\begin{array}{c}\text { Strongly } \\
\text { agree }\end{array}$ \\
\hline Visitor respects the local culture & 1 & 4 & 25 & 47 & 23 \\
\hline $\begin{array}{l}\text { Visitor participates in protecting } \\
\text { environment }\end{array}$ & 12 & 18 & 33 & 20 & 17 \\
\hline $\begin{array}{l}\text { Visitor purchases local goods or } \\
\text { services }\end{array}$ & 6 & 22 & 35 & 23 & 14 \\
\hline $\begin{array}{l}\text { Responsible tourism should be } \\
\text { promoted }\end{array}$ & 0 & 3 & 15 & 59 & 23 \\
\hline $\begin{array}{l}\text { The awareness of responsible } \\
\text { tourism of visitors after } \\
\text { participating in the tour }\end{array}$ & 4 & 14 & 28 & 33 & 21 \\
\hline
\end{tabular}

know more about Hungarian history. The tour guide will help them to understand the local culture. There was $47 \%$ of visitors agree and $23 \%$ of them strong agree to respects the local culture. They did not only visit landscape but they also purchased local goods or services in order to help the local community maintains the local handcraft.

The environment is a pillar of the triple bottom line of Corporate social responsibility (CSR). It is a reason why responsible tourism tour was designed with environmental protection activities. However, there was $37 \%$ of visitors were participations while $30 \%$ of others didn't take part in protecting the environment. They didn't participate in the activity because some of the responsible tourism packages only focus on culture instead of environment.

As we mentioned above, it was a low awareness of visitors about the concept of responsible tourism before participating on Responsible tourism tour. The fact that $35 \%$ of visitors haven't heard about responsible tourism while there was $45 \%$ of them met up with this concept but do not know what exactly it is. It was only $20 \%$ of visitors understood the concept of responsible tourism. However, responsible tourism tour raised tourist's awareness from $20 \%$ to $53 \%$. It is a good opportunity for tour operator and travel agency to develop responsible tourism tour in Budapest.

According to the definition of a tour guide, we know that duty and responsibility of a tour guide include all activities related to the tourist activities started from tourist arrival to a country, tour activities until departure activities. Responsible tourism tour requires tour guide have to raise tourist's awareness of responsible tourism. In another hand, tour guide should help visitors take their responsibility as a responsible tourist.

Table 2 gives data about the tour guide responsibility from the visitor points of view. Overall, the tourist was satisfied with the tour guide. The tour guide didn't discriminate against visitors. Tourist recognized that tour guide helped them to enhance their knowledge about responsible tourism (65\%). The tour guide provides a wide range of knowledge about the local culture which was $57 \%$ of visitors satisfied. In addition, Tour guide also let visitors know how to protect environment (38\%). However, 32\% of visitors didn't agree that tour guide shows them how to protect environments because some of them weren't good at this activity. Therefore, tour operator and travel agency must train the employee better. 
Table 2: Responsible tourism practices undertaken by tour guide (\%). (Source: Calculations on the basis of the survey, 2017.)

\begin{tabular}{|l|c|c|c|c|c|}
\hline \multirow{2}{*}{ Criteria } & \multicolumn{5}{|c|}{ Scale } \\
\cline { 2 - 6 } & $\begin{array}{c}\text { Strongly } \\
\text { disagree }\end{array}$ & Disagree & Neutral & Agree & $\begin{array}{c}\text { Strongly } \\
\text { agree }\end{array}$ \\
\hline $\begin{array}{l}\text { Tour guides help visitors to raise } \\
\text { awareness about responsible } \\
\text { tourism }\end{array}$ & 7 & 10 & 28 & 36 & 19 \\
\hline $\begin{array}{l}\text { Tour guides let visitors know how } \\
\text { to protect environment }\end{array}$ & 10 & 21 & 31 & 27 & 11 \\
\hline $\begin{array}{l}\text { Tour guides help visitors } \\
\text { understand the local culture and } \\
\text { respect their culture }\end{array}$ & 5 & 15 & 23 & 30 & 27 \\
\hline $\begin{array}{l}\text { Tour guides do not discriminate } \\
\text { against tourists }\end{array}$ & 3 & 6 & 27 & 36 & 28 \\
\hline
\end{tabular}

Responsible tourism wasn't focused only on visitor's behaviour but also the travel company's behaviour. It is important to know how the travel company presents their responsibility to their visitor, the local community, and stakeholders. Table 3 gives information about the assessment of CSR of travel companies.

It is clear that tourist was satisfied with what the company has represented in responsible tourism tour. Visitors were informed proper information $(81 \%)$. Most of the visitors experienced the same services as the committee of the tour package (45\%). It means that the travel company implemented and controlled their committee with the consumers very well.

Table 3: Cooperate social responsibility of travel company from the tourist's point of view (\%). (Source: Calculations on the basis of the survey, 2017.)

\begin{tabular}{|l|c|c|c|c|c|}
\hline \multirow{2}{*}{ Criteria } & \multicolumn{5}{|c|}{ Scale } \\
\cline { 2 - 6 } & $\begin{array}{c}\text { Strongly } \\
\text { disagree }\end{array}$ & Disagree & Neutral & Agree & $\begin{array}{c}\text { Strongly } \\
\text { agree }\end{array}$ \\
\hline $\begin{array}{l}\text { Visitors are informed proper } \\
\text { information about the tour package }\end{array}$ & 2 & 7 & 10 & 53 & 28 \\
\hline $\begin{array}{l}\text { Visitors experience the same } \\
\text { services as the committee of the } \\
\text { tour package }\end{array}$ & 13 & 17 & 25 & 35 & 10 \\
\hline $\begin{array}{l}\text { The quality of the tour package is } \\
\text { commensurate with the price that } \\
\text { visitors have spent }\end{array}$ & 10 & 16 & 23 & 33 & 18 \\
\hline $\begin{array}{l}\text { TO/TA invests in environmental } \\
\text { protection activities }\end{array}$ & 15 & 20 & 30 & 22 & 13 \\
\hline $\begin{array}{l}\text { TO/TA invests in community } \\
\text { cultural development activities }\end{array}$ & 4 & 16 & 25 & 34 & 21 \\
\hline $\begin{array}{l}\text { TO/TA shares the benefits with } \\
\text { local communities }\end{array}$ & 3 & 14 & 28 & 39 & 16 \\
\hline
\end{tabular}


In other hands, $51 \%$ of them receive value from the tour was commensurate with the price that they have spent.

It can be seen that tour operator/travel agency invested in improving the environment and reserved value of culture. Responsible tourism which concentrates on maximizing the positive impact is different with the other types of tourism. In addition, responsible tourism tour shares the benefits with local communities. Hence, it is necessary to maintain these investments in improving the environment and preserving culture.

In the sphere of tourism program, there are some special criteria to assess responsible tourism. The results of a survey presented in Table $4.60 \%$ was the highest percentage of visitors satisfied with the tourism program which organized protection environment activities. Therefore, tour operator should develop these activities on responsible tourism package. $33 \%$ of visitor agreed that the local people take part in some activities of tourism program while there was $27 \%$ of them didn't agree. We can explain this problem that some of responsible tourism hasn't had the participation of local people. Hence, tour operator should give a chance for local people to join in tourism packages. It helps the visitors to have a truly experiences with local culture and shares benefits with the community. Responsible tourism tour should cooperate with green label hotel and restaurant to raise tourist's awareness. However, responsible tourism tour in Budapest hasn't kept an eye on this issue. That's why there was $40 \%$ of visitor didn't recognize that accommodation and restaurant facilities use environmentally-friendly materials. In general, $42 \%$ of tourists were satisfied with tourism package while there were $13 \%$ of them very satisfied. It is a good opportunity for tour operator and travel agency to improve the quality of tourism program and promote responsible tourism.

As we mentioned before that responsible tourism tour raised visitor's awareness about their responsibility. Moreover, they are satisfied with the package because of the meaningful from their activities in the destination. It is a reason why $71 \%$ of visitors would like to enjoy other responsible tourism tour. It is clear that the increase of visitor's demand brings a big opportunity for tour operator/travel agency to promote responsible tourism packages.

It is important to know that visitors are satisfied with the responsible tourism tour and they would like to introduce the tourism package to others. There was $76 \%$ of visitors will recommend the package to their friends and family. There was $13 \%$ tourists do not want to suggest to others while $11 \%$ people hard to make their decision.

Table 4: The assessment of responsible tourism program (\%). (Source: Calculations on the basis of the survey, 2017.)

\begin{tabular}{|l|c|c|c|c|c|}
\hline \multirow{2}{*}{ Criteria } & \multicolumn{5}{|c|}{ Scale } \\
\cline { 2 - 6 } & $\begin{array}{c}\text { Strongly } \\
\text { disagree }\end{array}$ & Disagree & Neutral & Agree & $\begin{array}{c}\text { Strongly } \\
\text { agree }\end{array}$ \\
\hline $\begin{array}{l}\text { Tourism programs encourage } \\
\text { tourists to protect the natural } \\
\text { environment }\end{array}$ & 8 & 12 & 20 & 35 & 25 \\
\hline $\begin{array}{l}\text { Some activities of tourism program } \\
\text { are organized by local people }\end{array}$ & 10 & 17 & 39 & 21 & 13 \\
\hline $\begin{array}{l}\text { Accommodation and restaurant } \\
\text { facilities use environmentally- } \\
\text { friendly materials }\end{array}$ & 16 & 24 & 31 & 19 & 10 \\
\hline $\begin{array}{l}\text { Tourist satisfaction with } \\
\text { responsible tourism tour }\end{array}$ & 9 & 16 & 29 & 42 & 13 \\
\hline
\end{tabular}




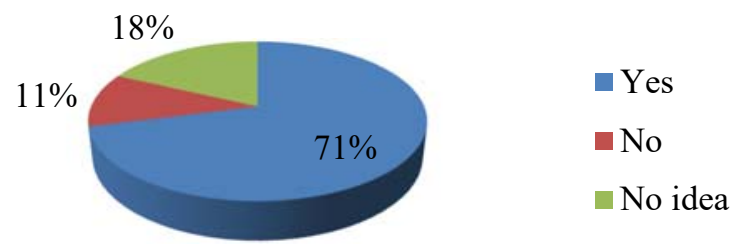

Figure 1: Visitor's demand of responsible tourism tour.

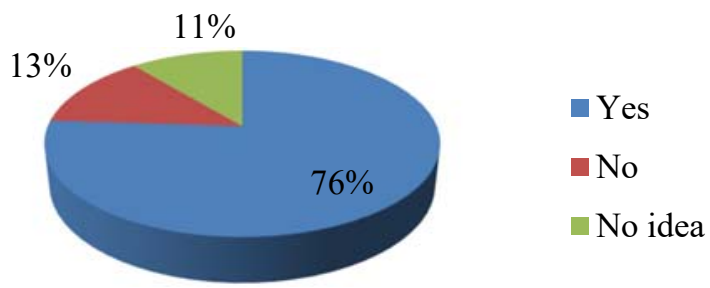

Figure 2: Visitor will recommend the responsible tourism tour to others.

\section{CONCLUSIONS}

The aim of the study was to contribute to a deep understanding of the responsible tourism phenomenon using a demand-side approach. Adopting a mixed-methods approach, whereby a qualitative study acts as an entry for a quantitative study, the findings revealed that tourist's awareness about responsible tourism was improved. As we mentioned above, it was a low awareness of visitors about the concept of responsible tourism before participating on Responsible tourism tour. The fact that $35 \%$ of visitors haven't heard about responsible tourism while there was $45 \%$ of them met up with this concept but do not know what exactly it is. It was only $20 \%$ of visitors understood the concept of responsible tourism. However, responsible tourism tour raised tourist's awareness from $20 \%$ to $53 \%$.

The most of tourists are keen to be involved in the environmental improvement. Further, the research found that tourists respect the local culture, which is a positive behaviour. However, the proportion of visitor purchases good and services was not that much (only $37 \%$ ). Therefore, we have to encourage tourist to purchase local goods or services to share the benefit with the community.

Tourists were satisfied with the tour guide. They recognized that tour guide helped them to enhance their knowledge about responsible tourism (65\%). The tour guide provides a wide range of knowledge about the local culture and guides them on how to respects the local culture and protect the environment. However, some of the tour guides weren't good at guiding tourist on how to protect the environment. Therefore, tour operator and travel agency must train the employee better.

It is clear that tourists were satisfied with what the company had represented in responsible tourism tour. The travel company implemented and controlled their committee with the consumers very well. In addition, it is necessary to maintain these investments in improving 
the environment and preserving culture. However, there was $40 \%$ of visitors didn't recognize that accommodation and restaurant facilities use environmentally-friendly materials. It will be better? if the hotel and restaurant facilities use environmentally-friendly materials in the tour.

It is important to know that there was $71 \%$ of visitors would like to enjoy other Responsible Tourism Tour while $76 \%$ of them would recommend the package to others. It is clear that the increase of visitor's demand brings a big opportunity for Tour operator/ Travel agency to promote Responsible tourism packages.

These conclusions are significant for both tourists and travel company to take their responsibility for sustainable tourism. On one hand, this study provides further insights into the scientific debate on responsible tourism. Meanwhile, we suggest solutions to improve the quality of responsible tourism in Budapest.

\section{ACKNOWLEDGEMENTS}

This research was partially supported by Budapest Business School. We thank our colleagues from the Faculty of Commerce, Catering and Tourism who provided insight and expertise that greatly assisted the research. We would like to express our deep gratitude to our friends for their help in collecting questionnaires.

Finally, we wish to thank our family for their support and encouragement throughout our study.

\section{REFERENCES}

[1] Atinay, M. \& Hussain, K., Sustainable tourism development: A case study of North Cyprus. International Journal of Contemporary Hospitality Management, 17(3), pp. 272-280, 2005.

[2] Medina, L.K., Ecotourism and certification: Confronting the principles and pragmatics of socially responsible tourism. Journal of Sustainable Tourism, 13(3), pp. 281-295, 2005.

[3] Mortara, A., Il consumatore etico esiste davvero. Presented at 6th International Congress Marketing Trends, Venice, 2007.

[4] Responsible Travel Handbook, www.transitionsabroad.com/listings/travel/ responsible/responsible_travel_handbook.pdf. Accessed on: 15 Mar. 2016.

[5] Harold Goodwin Taking Responsibility for Tourism. www.haroldgoodwin.info/ uploads/fvHaroldGoodwinTravellersClub16May2011.do. Accessed on: 26 Mar. 2016.

[6] United Nations - World Commission on Environment and Development, Our common future. www.un-documents.net/wced-ocf.htm. Accessed on: 25 Aug. 2013.

[7] The Fifth Community Programme for Environment and Sustainable Development. http://eur-lex.europa.eu/legal-content/EN/TXT/?uri=LEGISSUM\%3Al28062. Accessed on: 1 Apr. 2016.

[8] Clifton, J. \& Benson, A., Planning for sustainable ecotourism: The case for research ecotourism in developing country destinations. Journal of Sustainable Tourism, 14(3), pp. 238-254, 2006.

[9] Budeanu, A., Sustainable tourist behaviour: A discussion of opportunities for change, International Studies of Consumer Studies, 31, pp. 499-508, 2007.

[10] Meric, H.J. \& Hunt, J., Ecotourist's motivational and demographic characteristics: A case of North Carolina travelers. Journal of Travel Research, 36(4), pp. 57-61,1998.

[11] Lori, M. \& Volpi, F., Scegliere il "bene”, Indagine sul consumo responsible, Franco Agenli: Milan, 2007. 
[12] European Charter for Sustainable and Responsible Tourism, www.ceeweb.org/ wpcontent/uploads/2011/12/Commented_Tourism_Charter_CEEweb.pdf. Accessed on: 19 Apr. 2016.

[13] Center for Ecotourism and Sustainable Development (CESD) - The International Ecotourism Society (TIES), www.responsibletravel.org/docs/Ecotourism Handbook_III.pdf. Accessed on: 19 Apr. 2016.

[14] Trade Profiles 2010, WTO 2010. www.wto.org/english/res_e/booksp_e/anrep_e/ trade_profiles10_e.pdf. Accessed on: 23 Apr. 2016.

[15] Wearing, S., Volunteer Tourism: Experiences that Make a Difference, CABI Publishing: Oxford, 2001.

[16] Chafe, Z., Consumer Demand and Operator Support for Socially and Environmentally Responsible Tourism, Working Paper No. 104. Centre on Ecotourism and Sustainable Development \& The International Ecotourism Society: Washington, DC, 2005.

[17] Choi, G., Parsab, H.G., Sigala, M. \& Putrevu, S., Consumers' environmental concerns and behaviors in the lodging industry: A comparison between Greece and the United States. Journal of Quality Assurance in Hospitality and Tourism, 10, pp. 93-112, 2009. 